\title{
Combat fitness program and its effect on physical condition
}

\section{Programa de fitness de combate y su efecto en la condición física}

Klever Geovanny Lema Villalba. ${ }^{1}$, Ángel Aníbal Sailema Torres. ${ }^{2}$, Betty Paulina Tobar Lozada $^{3} \&$ Segundo Víctor Hernández del Salto. ${ }^{4}$

Recibido: 10-02-2019 / Revisado: 15-02-2019 /Aceptado: 04-03-2019/ Publicado: 14-06-2019

\begin{abstract}
.
DOI: https://doi.org/10.33262/cienciadigital.v3i2.5.544

The physical condition is considered an important aspect within the personal appearance, that's why this study proposes the realization of a Fitness Combat program to analyze the physical condition of participants who permanently attend the gym Skainos in the city of Ambato. The population consisted of 61 participants, all male, for which a qualitative-quantitative methodology was proposed, carried out through a programmed work of combined exercises of personal defense, boxing and martial arts with the accompaniment of a musical sequence designed to enhance the aerobic capacity of the people. The program had a duration of 10 months; as for the analysis of the physical condition the Cooper test was applied in two moments, before and after the accomplishment of the program, the applied test had a duration of 12 minutes, which verifies the distance crossed in the determined time. The results in the physical

${ }^{1}$ Universidad Técnica de Ambato, Facultad de Ciencias Humanas y de la Educación, Maestría en Gestión y Administración Deportiva. Ambato, Ecuador. klema3157@uta.edu.ec

${ }^{2}$ Universidad Técnica de Ambato, Facultad de Ciencias Humanas y de la Educación, Carrera de Cultura FísicaPedagogía de la Actividad física y Deporte. Ambato, Ecuador. aa.sailema@uta.edu.ec

${ }^{3}$ Universidad Técnica de Ambato, Facultad de Ciencias Humanas y de la Educación, Maestría en Gestión y Administración Deportiva. Ambato, Ecuador. betipautobar@hotmail.com

${ }^{4}$ Universidad Técnica de Ambato, Facultad de Ciencias Humanas y de la Educación, Carrera de Cultura Física. Ambato, Ecuador.vhernandez@uta.edu.ec
\end{abstract}


condition after the application of the program, shows a significant improvement in the study sample, with which there is an indisputable improvement of the aerobic physical condition, including the recovery of cardiorespiratory indicators thanks to the frequency, duration and intensity of exercise.

Keywords: Physical condition, Fitness Combat, routines, analysis.

\section{Resumen.}

La condición física es considerada un aspecto importante dentro de la apariencia personal, es por eso que el presente estudio propone la realización de un programa de Fitness de Combate para analizar la condición física de los participantes que asisten permanentemente al gimnasio Skainos de la ciudad de Ambato. La población estuvo conformada por 61 participantes todos de sexo masculino, para lo cual se propuso una metodología cuali-cuantitativa, realizada mediante un trabajo programado de ejercicios combinados de defensa personal, boxeo y artes marciales con el acompañamiento de una secuencia musical diseñada para potenciar la capacidad aeróbica de las personas. El programa tuvo una duración de 10 meses; en cuanto al análisis de la condición física se aplicó el test de Cooper en dos momentos, antes y después de la realización del programa, la prueba aplicada tuvo una duración de 12 minutos, la cual verifica la distancia recorrida en el tiempo determinado. Los resultados en la condición física tras la aplicación del programa, evidencia una mejora significativa en la muestra de estudio, con lo cual existe una mejora indiscutibles de la condición física aeróbica, incluyendo la recuperación de indicadores cardiorrespiratorios gracias a la frecuencia, duración e intensidad del ejercicio.

Palabras claves: Condición física, fitness, combate, rutinas, análisis.

\section{Introduction}

The physical condition is present in all human movement, the development of strength, endurance, speed, flexibility are qualities determined by genetic factors. The physical condition has an intimate relation with the sport development, to verify its progress, always taking into account some individual parameters of the person so that it can face physical tasks with the maximum efficiency and performance, a relation between physical activity, physical condition and self-concept (Guillamón, 2019), which implies individual qualities and will; in short the development of the physical condition depends on an adequate training and of the psychological capacities. 
Delgado Floody N., (2015) mentions that physical condition benefits to maintain an adequate weight and enjoy good health, increases the maximum consumption of oxygen depending on the duration, intensity, and frequency of training. Before starting a physical activity program, it is advisable to see your doctor for an assessment of your physical condition. At present, the general population is exposed to serious obesity problems, giving priority to sedentary activities such as: excessive use of the Internet, television, computer games; thus promoting lack of exercise, considered as one of the major risk factors for heart disease and problems, arteriosclerosis, hypertension, and respiratory diseases (Prieto, 2018).

According to Fernandez M., (2001) expresses that the sport physical activity influences the maintenance of the health, since the physical activity is at the disposal of whoever wishes to increase his physical state, at the same time he specifies that the classes of physical education, present a scarce process to develop the physical condition, which deserves a sport physical treatment to obtain the physical and psycho-social benefits (Schwartzmann, 2018). The physical practice entails an expenditure of energy putting the organism in movement at a corporal, psychic and emotional level (García, 2011, p. 6). With the above we can deduce that there is a relationship in the field of physical and psychological condition, where individual self-esteem helps to maintain physical condition, promoting in people security and autonomy, channeling energy better to focus on other activities (Morilla Cabezas, 2001).

It is important to emphasize that physical activity and a balanced diet favour health, improve endurance and reduce the risk of suffering from cardiovascular diseases (Rodríguez, 2019). Therefore, encouraging good habits in exercise routines allows you to improve and/or maintain an appropriate physical condition, so proper practice with fitness routines makes the difference in maintaining a good lifestyle.

In South America, combat fitness appears officially in 2006, no doubt and with greater intensity than the practice of aerobics, is based on short routines but that mean great effort, this physical activity tones the muscles quickly, the time of each class is approximately fifty minutes to an hour, intensity, coordination and posture is very important to improve people's physical condition and personal health (Hendry, 2018), the music that accompanies the class is motivating so that the session is always intense and has an expectation of attention for the execution of the movements, in short the fitness presents a set of gymnastic exercises and activities that integrate the cardiorespiratory, hematocirculatory, and psychoneurological system (Ortega, 2008).

In Ecuador, combat fitness appears in 2010, comes with a great impact as a sport of great intensity, where burning calories is more beneficial than in the practice of other sports, this aerobic activity combines techniques taken from different disciplines such as boxing, karate, tae kwon do, Kick boxing, muay thai, among others. The daily practice increases every day more in the different cities of Ecuador by its great demand in gyms; its creator is Francisco Sanchez of the city of Quito, black belt in karate do, founder of the Samuari Fight, composed 
the music with effects of blows for the accomplishment of the routines and exercises, the instructors have created some personalized systems of fitness of combat, they are people who have knowledge of martial arts, they have their own music with impacts of blows so that the practices are understandable and motivating.

Despite the increase in evidence in favor of a physically inactive lifestyle, most of society remains sedentary, knowing that its consequences are the proliferation of different diseases Quiñones, (2012, p. 6). The statistics indicate that 50\% of the adult society are physically inactive, that is to say, they do not tend to practice physical exercises, $30 \%$ do not practice any type of physical activity in their free time, bearing in mind that physical inactivity has unfavourable consequences for their health. Faced with this problem, many international bodies of health and sport, recommend physical activity, at least three times a week is recommended to maintain good physical and mental fitness, it is recommended that at least 30 minutes of physical activity to help oxygenate the brain, which contributes to the improvement in the physical and psychic study (Mocha-Bonilla, et al., 2018); progressively after a low-impact program, increase the intensity according to personal progress, monitor the states in the sports form of the subjects according to the load and training (PorrasAlvarez, 2019).

In the city of Ambato, the gym Skainos Gym proposes a new alternative for the application of physical activity, which contributes to maintain an optimal state of health, thanks to the large number of participants, a need is born to implement schedules for the practice of combat fitness, whose consumption of calories when practicing this physical activity plus an adequate diet is important to achieve a good physical condition. For this reason, the study aims to analyze the physical condition of participants who practice combat fitness.

\section{Methodology}

This research was developed because of a quali-quantitative approach. Quantitative - because it allowed to verify in a reliable way the qualities of the participants of the study the application of the combat fitness. Qualitative - because the physical condition of each participant was examined.

The modality was field because it required the researcher to go to the place where the facts were developed and be able to compile the information of the variables of the study, different techniques and instruments of investigation were applied for the fulfillment of the proposed objective.

Subjects: The study of the development of the physical condition in the sport environment, directed in the different ages, has verified that with its constant practice it obtains the acquisition of abilities and capacities, by means of an adequate training; these physical characteristics are developed of different form in each person, depending on its age, sex, obtaining as result the improvement of the health. According to this perspective, the sample 
was composed by 61 participants of Skainos Gym of the city of Ambato, all of masculine sex, in age from 30 to 39 years.

Materials: For this research, we used Kenneth H Cooper's test, which consists of assessing the aerobic physical condition of athletes in a time of 12 minutes, which verifies the distance traveled (Garcia, 2011). A SONY chronometer and the athletic track of Federación Deportiva de Tungurahua were used for the application of the test.

Protocol: Firstly, the participants of Skainos Gym from the city of Ambato were socialized on the subject of Cooper's test, the place where the activity takes place, the time to be used, the route established in the test, and the disciplinary rules of the practice. The tasks were directed to the distribution in working groups of 20-21 people for each group both in the first and in the second shot.

\section{Implementation of the programme.}

\section{Procedure}

The combat fitness class consists of three fundamental parts: the first part warms up, where the body is prearranged to perform physical activity, the second part presents the development of the class, where the upper and lower extremities interfere, their elbows complements, knees that help form the sequence for the choreography, and the third are the displacement in the four cardinal points, where the different methods are used maintaining the sequence of an imaginary combat. The practice of fitness improves the time of physical and mental reaction, teaches basic knowledge of self-defense, with techniques of boxing strokes and different systems of martial arts.

The Combat Fitness is an aerobic training program that seeks to improve physical condition by combining movements and positions of martial arts techniques, the purpose of the practice is to tone the body, burn between 600 to 800 calories to the rhythm of music, in short is a discipline that is inspired by various martial arts programs, whose purpose is not to teach fighting, but whoever practices it discharges energy with blows and kicks into the air without any contact, thus benefiting physical and mental health.

The baby class is simple, orderly, understanding, intense, entertaining and above all fun, each session begins with a warm up of the joint movements, gradually incorporating boxing techniques, while the session advances increases kicks, blows and movements, all this prior to the indication of the instructor who has programmed the choreography and music, which is a fundamental factor in the practice of this discipline. The themes are adapted with sound effects for the execution of blows and kicks, generating adrenaline and enthusiasm. Understood in the matter they recommend that the music has of 130 to $150 \mathrm{rpm}$, nevertheless, exists themes with an rpm of 170 to 180 , used in a class for people with suitable physical condition by its rapidity in the execution of the different blows. Its application depends largely on the instructor and the way to assemble the choreography, emphasizes a simple technique for initial learning, taking into account that many of the participants do not have knowledge of martial arts, the movements should be easy to perform so that everyone is 
motivated captivating this way the participation of all, also the sessions consist of the work of laterality, ie the first part of the practice is done in the position of hand and left foot, for later the second part to do with the guard foot and right hand. The teaching method is visual and verbal, the visual instructions are the first that the group captures by default, look and try to make the same movements as the instructor, the same one that must have a correct execution technique, depends on the preparation and good technical foundations so that the rest imitates the movements and avoid possible injuries. The verbal is a complement of the visual instruction; you must have a good balance between the two to achieve a proper technical process in practice. The primary objective of a combat fitness class is the training of cardiovascular and muscular endurance through the combination of elementary boxing movements and the different techniques of martial arts, producing benefits physically, psychologically and emotionally. The program lasted 10 months.

Data analysis: In the analysis of the research, bibliographic sources of different scientific articles were used, as well as Kenneth H Cooper's test, which was applied in the study, with the fundamental purpose of comparing, comparing and analyzing the results obtained. The numerical values obtained in the application tests facilitated the interpretation of each of the results obtained.

\section{Results.}

The data were analyzed based on the distance traveled (meters) during the established time.

Table 1. Reference scale for assessing physical condition using the Cooper test.

\section{AGE OF MEN}

LEVEL

13-19

20-29

30-39

40-49

50-59

$\begin{array}{cccccr}\text { VERY BAD } & <2100 & <1950 & <1900 & <1850 & <1650 \\ \text { MALA } & 21002200 & 19502400 & 19002100 & 18502000 & 16501850 \\ \text { REGULAR } & 22002500 & 24002650 & 21002350 & 20002250 & 18502100 \\ \text { GOOD } & 25002750 & 26502850 & 23502500 & 22502500 & 21002300 \\ \text { VERY GOOD } & 27503000 & 28502850 & 25002700 & 25002650 & 23002550 \\ \text { EXCELLENT } & >3000 & >2850 & >2700 & & >2650\end{array}$

Source: Prepared by the authors. 


\section{S) Ciencia}

ISSN: 2602-8085

Vol. 3, N².5, p. 171-180, abril - junio, 2019

The data obtained in the accomplishment of the Cooper test, is determined by the valuation that is given to each participant in dependence of his physical state, thus we have the following scale: very bad, bad, medium, good, very good, excellent. These data established by investigations already carried out, allow us to give the respective statistical values, where it was possible to discover percentages in the two takes, before and after the application of the Fitness program. Figure 1 shows an average value of $1812 \mathrm{~m}$ in the first shot of the participants of the study, which gives a bad to regular appreciation.

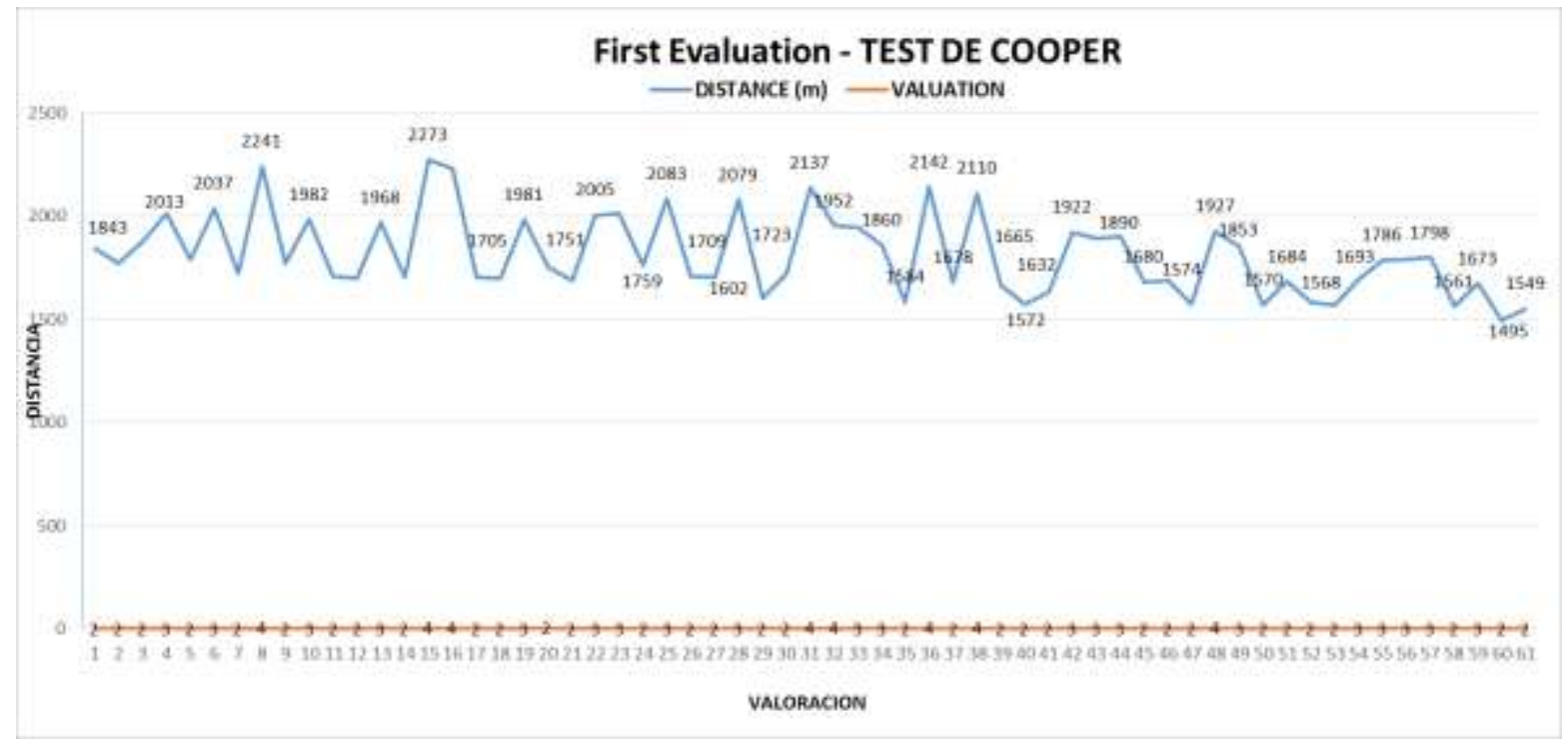

Figure 1. Data from the first evaluation

Source: Prepared by the authors.

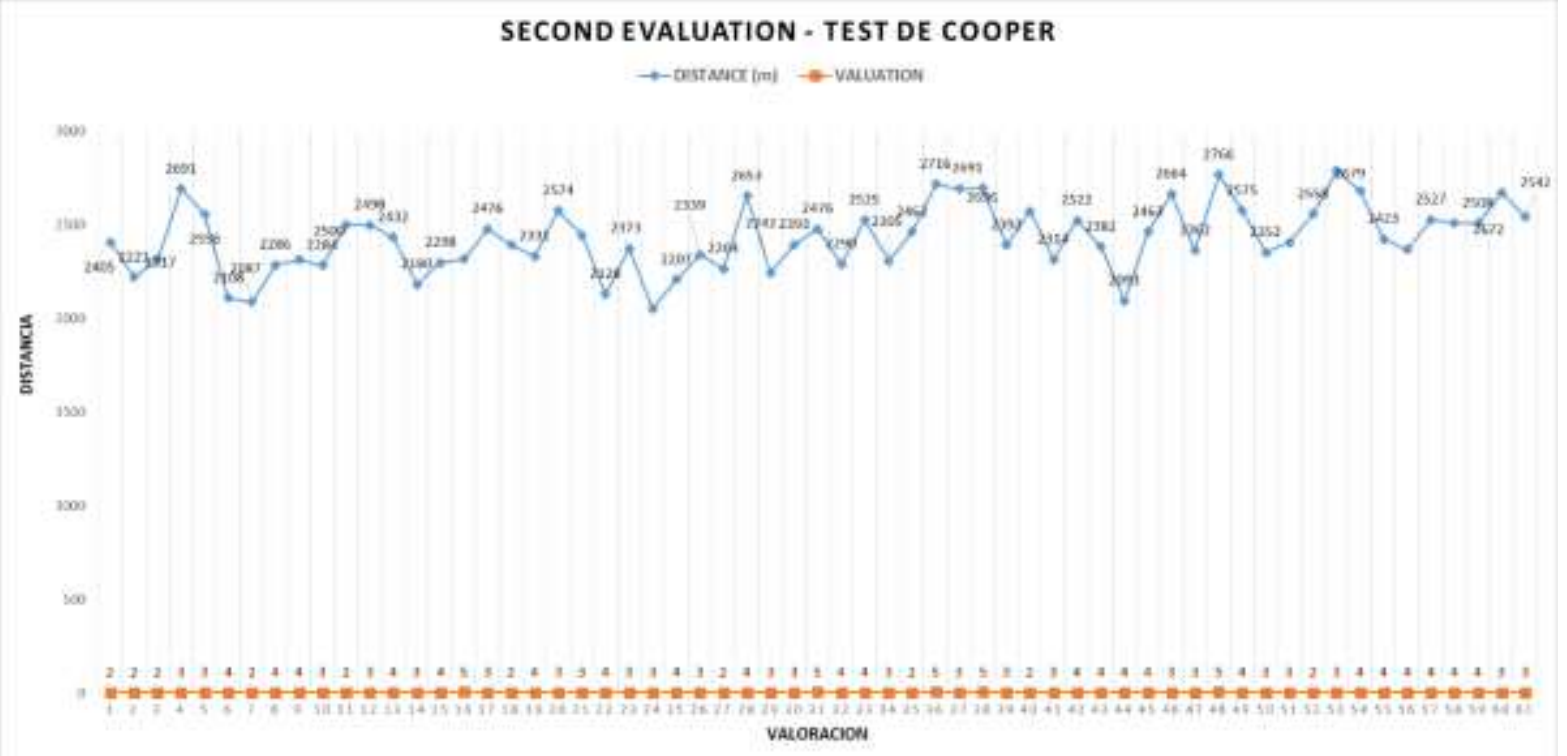

Figure 2. Data from the second evaluation

Source: Prepared by the authors. 
In figure 2, it is possible to appreciate the average results obtained in the second shot in the study sample; it has been verified that there is a significant improvement in the physical condition of the participants, thanks to the physical work carried out, where it is clearly possible to confirm that the practice of combat fitness notably improves the physical condition, since in the second shot, after 10 months, the average value was $2425 \mathrm{~m}$ in the participants, which gives a good valuation.

\section{Conclusions.}

Satisfactorily it can be concluded that the sport physical practice of combat fitness helps significantly to improve the physical condition, however it is necessary to make a proper planning in a personalized and dosed manner, according to the chronological age and gender of the person, factors with which you can design an exercise program in a personalized way, being indispensable an adequate medical checkup.

The intensity and time of the program are aimed at improving the health and well-being of people who practice combat fitness; in short, there is scientific evidence that has shown that there are indisputable improvements in aerobic fitness, including the recovery of cardiorespiratory indicators and metabolism in the human body. Therefore, the frequency, duration and intensity of exercise is a fundamental factor for the improvement of aerobic capacity in people.

After an analysis for the development of the physical condition, it can be argued that there are different methods and tests to assess physical condition, which opens the possibility of incorporating new lines of research from this study.

There are different proposals to improve the physical condition, the important thing is to plan and to consolidate, so that the proposed objectives can be verified and refuted each one of their stages. It is possible to corroborate the satisfactory effect of the results obtained in the applied sample.

\section{References}

Delgado Floody, P., Caamaño Navarrete, F., Guzmán Guzmán, I. P., Jerez Mayorga, D., RamírezCampillo, R., Campos Jara, C., ... \& Díaz Inostroza, H. (2015). Niveles de obesidad, glicemia en ayuno y condición física en escolares chilenos. Nutrición Hospitalaria, 31(6), 2445-2450. Floody, N. (2015). Niveles de obesidad. Nutricion Hospitalaria.

Fernandez. (2001). Investigacion accion aplicado al bloque de contenidos de condicion fisica. Revista internacional de medicina y ciencias en la actividad fisica, 84-99.

Garcia, G. (2011). Relacion entre autoconcepto y condicion fisica. Revista de psicologia del deporte.

Garcia, J. (2011). Condicion fisica relacionada con la salud. Revista de investigacion en educacion. 
Guillamón, A. R. (2019). Actividad física, condición física y autoconcepto en escolares de 8 a 12 años. Retos: nuevas tendencias en educación física, deporte y recreación, 35, 236-241.

Hendry, A. S. (2018). La evolución contemporánea del fitness. Revisión anual de ecología, evolución y sistemática., 49, 457-476.

Mocha-Bonilla, J. A., Guerrero Sánchez, J., Jimenez, L. A., Poveda, M. P., Barona-Oñate, R., \& Guerrero, A. G. (2018). Analysis of the Body Composition Index and Basal Metabolic Rate Through the Mobile Application eHealth-UTA. International Conference on eDemocracy \& eGovernment (ICEDEG), 386 - 391. doi:10.1109/ICEDEG.2018.8372326

Morilla Cabezas, M. (2001). Beneficios psicológicos de la actividad física y el deporte. DSOACE.

Ortega, F. B. (2008). Physical fitness in childhood and adolescence: a powerful marker of health. nternational journal of obesity,, 32.

Porras-Alvarez. (2019). Variabilidad de la frecuencia cardiaca. entrenamiento deportivo(2), 16.

Prieto, M. B. (2018). Sedentarismo y salud: efectos beneficiosos de la actividad física en estudiantes universitarios. Revista electrónica de investigación y docencia creativa., 7, 79-84.

Quiñones. (2012). Condicion fisica, actividad fisica y dificultades para su realizacion. Revista medica, 24.

Rodríguez, J. H. (2019). Recomendaciones para el tratamiento médico de la obesidad exógena en el nivel primario de atención. . Revista Cubana de Medicina General Integral,, 3-24.

Schwartzmann, L. (2018). Calidad de vida relacionada con la salud: aspectos conceptuales. 


\section{PARA CITAR EL ARTÍCULO INDEXADO.}

Lema Villalba, K., Sailema Torres, Ángel, Tobar Lozada, B., \& Hernández del Salto, S. (2019). Combat fitness program and its effect on physical condition. Ciencia Digital, 3(2.5), 176-185. https://doi.org/10.33262/cienciadigital.v3i2.5.544

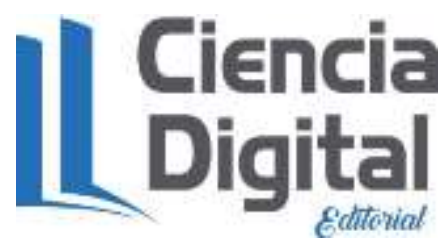

El artículo que se publica es de exclusiva responsabilidad de los autores y no necesariamente reflejan el pensamiento de la Revista Ciencia Digital.

El artículo queda en propiedad de la revista y, por tanto, su publicación parcial y/o total en otro medio tiene que ser autorizado por el director de la Revista Ciencia Digital.
